\title{
Long-term individual sighting history database: an effective tool to monitor satellite tag effects on cetaceans
}

\author{
D. Gendron ${ }^{1, *}$, I. Martinez Serrano ${ }^{2}$, A. Ugalde de la Cruz ${ }^{1}$, J. Calambokidis ${ }^{3}$, \\ B. Mate ${ }^{4}$ \\ ${ }^{1}$ Centro Interdisciplinario de Ciencias Marinas, Instituto Politécnico Nacional, La Paz, Baja California Sur CP 23096, Mexico \\ ${ }^{2}$ Museo de Zoología, Facultad de Biología, Universidad Veracruzana, Xalapa, Veracruz CP 91000, Mexico \\ ${ }^{3}$ Cascadia Research, 2181/2 W $4^{\text {th }}$ Ave, Olympia, Washington 98501, USA \\ ${ }^{4}$ Marine Mammal Institute, Oregon State University, Hatfield Marine Science Center, Newport, Oregon 97365, USA
}

\begin{abstract}
During the last 3 decades, tagging technology has been used to study different aspects of cetacean ecology. Tags implanted in animal's blubber, muscle and surrounding tissue have produced successful results, providing information on long-term movements. However, apart from the reports of 'divots' (depressions) and swelling at the tag sites in re-sighted large whales, little has been published about the long-term effects of tagging. Based on sighting history databases of photo-identified blue whales, we monitored the wound site of a satellite tag on an adult female blue whale over a period of $16 \mathrm{yr}$ (1995 to 2011). This report describes the swelling reaction to a broken subdermal attachment from a tag designed early in the evolution of large whale tagging. The tag attachment remained embedded for a decade (much longer than expected), and may have affected the female's reproductive success during this period. The whale's calving history showed a total of 3 calves; 2 were prior to, and one ocurred after, the swelling period (1999 to 2007). We demonstrate the value of long-term monitoring programs in evaluating tag impacts, especially on endangered species.
\end{abstract}

KEY WORDS: Satellite tag $\cdot$ Long-term effect $\cdot$ Monitoring $\cdot$ Calving interval $\cdot$ Blue whale

\section{INTRODUCTION}

For more than 3 decades, radio- and satellite-tagging technology has been used to track movements, diving, acoustic and foraging behaviors of whales (Mate \& Harvey 1983, Watkins \& Tyack 1991, Goodyear 1993, Croll et al. 1998, Zerbini et al. 2006, Heide-Jørgensen et al. 2006, Davis et al. 2007, Garrigue et al. 2010, Kennedy et al. 2013). In particular, the Oregon State University Marine Mammal Program has been very successful in tracking hundreds of large whales using implanted tags (including 12 stocks of 7 different species; Mate et al. 2007), show-

${ }^{*}$ Corresponding author: dgendron@ipn.mx ing how improvements in the size of the transmitter (Telonics ST-15) and attachment systems have made it possible to design a more effective implantable tag.

In the North Pacific, at least 180 tags have been implanted in blue whales. Information gathered from these tagged blue whales has contributed to a better understanding of their migration patterns (Mate et al. 1999) and habitat uses (Bailey et al. 2009), as well as promoting conservation areas for this endangered species (Etnoyer et al. 2004). The scope of these large-scale studies (Block et al. 2011) and the availability of these tags in the market have rapidly raised an interest in tagging research on smaller cetaceans

() The authors 2015. Open Access under Creative Commons by Attribution Licence. Use, distribution and reproduction are unrestricted. Authors and original publication must be credited. 
(Andrews et al. 2008, Schorr et al. 2009, Baird et al. 2012, Durban \& Pitman 2012). Moreover, interest in tagging multiple life history stages to study predator ecology and to effectively manage marine populations has increased (Hazen et al. 2012). Thus, these new approaches emphasize the need to better understand the long-term effects of tagging, especially if non-adult individuals or smaller species are to be specifically targeted in future studies.

A recent review of $30 \mathrm{yr}$ of published literature on the effects of invasive marking on marine mammals (Walker et al. 2011) indicated that some technologies may cause short-term physiological responses (e.g. increased acute-phase proteins) and injuries (e.g. subcutaneous hemorrhaging and wound discharge) in small animals, and in some species, changes in survival rates have also been observed. Mate et al. (2007) suggested that the effect of tags on large whales was still open to debate, reporting that over 40 tagged whales had been re-sighted (out of 427 they tagged), and although cases of localized (3 to $10 \mathrm{~cm}$ ) and regional (30 to $60 \mathrm{~cm}$ ) swelling around some tag sites were observed, most of these effects did not persist and none were deemed debilitating. However, this inference was based on observations made over short periods of time relative to the long life span of the whales. Few focused assessments on the morphological effects of implanted tags in other whale species have been published. Robbins et al. (2013) described the effects of implant tagging on humpback whales Megaptera novaeangliae, reporting broad swellings that persisted over extended periods (at least $391 \mathrm{~d}$ in one case) and appeared to be related to tag breakage or body location. Best \& Mate (2007) reported only one case of localized swelling in 10 tagged southern right whales Eubalaena australis, but also described divots and scars often associated with cyamids (Cyamus sp.) as a common feature of tag wound sites. An assessment of long-term survival (20 to $30 \mathrm{yr}$ ) using photo-identification of 7 humpback whales $M$. novaeangliae radio-tagged from 1976 through 1978 was recently published (Mizroch et al. 2011); however, little information was reported on the tag sites or long-term effects. Overall, the scarcity of reports on the effects of satellite tags on cetaceans reflects the lack of systematic monitoring programs, or research programs that have not yet published their results. Long-term individual sighting histories gained from such monitoring programs are extremely valuable in the assessment of tag effects.

The photo-identification of individual blue whales (Sears et al. 1990) has proven useful to investigate movement patterns (Calambokidis et al. 1990, 2009,
Pike et al. 2009, Wall et al. 2009), along with other population parameters (Calambokidis \& Barlow 2004, Ramp et al. 2006, Ugalde de la Cruz 2008), social structure (Costa-Urrutia et al. 2013) and health assessments (Acevedo-Whitehouse et al. 2010, Martinez-Levasseur et al. 2011, 2013, Flores-Cascante \& Gendron 2012). We used the individual sighting history of an adult female blue whale photographed in the Gulf of California (Centro Interdisciplinario de Ciencias Marinas [CICIMAR] catalog), off the coast of California (Cascadia Research Collective [CRC] catalog) and at the time of tagging (Oregon State University Marine Mammal Program [OSU]) to document a satellite tag wound healing over a 16 yr period.

\section{MATERIALS AND METHODS}

Blue whales from the southwestern Gulf of California have been monitored annually since 1993 by CICIMAR researchers using a photo-identification method developed for the species by Sears et al. (1990). Gulf of California surveys were conducted aboard a $9 \mathrm{~m}$ inboard diesel vessel and a $7 \mathrm{~m}$ outboard-powered skiff during 3 to $6 \mathrm{~d}$ at sea (January to May) between the cities of Loreto and La Paz. Each blue whale was identified by photographing both flanks and taking a skin/blubber biopsy (unless the individual had been previously sampled; Gendron \& Ugalde de la Cruz 2012), resulting in a catalog of 750 unique individuals through 2013. Off the California coast, photographic identification has been conducted since 1986 using both dedicated small boat surveys and opportunistic platforms (Calambokidis et al. 1990, 2009, Calambokidis \& Barlow 2004), resulting in the identification of more than 2000 unique individuals through 2011. A configuration of the surface-mounted satellite tag used on the monitored whale (2 sub-dermal attachments, each consisting of cast bronze temple toggles mounted to stainless steel posts holding the tag to the whale's back), as well as a description of the tagging procedures are provided in Mate et al. (2007).

\section{RESULTS}

The blue whale subject of this paper (CICIMAR ID \#75) was first photographed in the southwestern Gulf of California on 13 April 1994, accompanied by a calf (Table 1). The whale was subsequently observed off California on 10 September 1995, and tagged on its left side with a Telonics ST-6 tag in a surface- 
Table 1. Sighting and calving history as well as swelling observation of the tagged blue whale female monitored between 1994 and 2011 during winter in the southwestern Gulf of California (GC), and during summer off the coast of California (CA). The period of tag attachment is shaded; $(-)$ indicates data missing

\begin{tabular}{|cccc|}
\hline Year & Area & Swelling & Calving history \\
\hline 1994 & GC & None & Calf \\
1995 & CA & None & No calf \\
1996 & GC & Not observable & Calf \\
1997 & - & - & - \\
1998 & - & - & - \\
1999 & CA & $30-60 \mathrm{~cm}$ & No calf \\
2000 & GC & Not observable & No calf \\
2001 & - & - & - \\
2002 & GC-CA & $>60 \mathrm{~cm}$ & No calf \\
2003 & GC-CA & $>60 \mathrm{~cm}$ & No calf \\
2004 & GC & $>60 \mathrm{~cm}$ & No calf \\
2005 & GC & $>60 \mathrm{~cm}$ & No calf \\
2006 & GC & $30-60$ cm open wound & No calf \\
2007 & GC & Not observable & No calf \\
2008 & - & - & - \\
2009 & GC-CA & Scar & No calf \\
2010 & - & - & - \\
2011 & GC & Scar & Calf \\
\hline
\end{tabular}

(Table 1). In 2009, no apparent swelling was observed, but the wound remained open (Fig. 1e). The whale was last seen in 2011 with a scar (closed wound) present at the tag site (Figs. 1f \& 2d).

The sighting history of whale ID \#75 indicates that this individual has been sexually mature since at least 1994, when first photographed with a calf (Table 1). The whale was a productive female, rearing 2 calves in 3 yr (1994 to 1996) before we observed the granuloma in 1999. During the 8 yr swelling period documented from 1999 to 2007 (not including 2001 when this individual was not seen), there was no calf observed accompanying her until the winter of 2011 (Table 1).

\section{DISCUSSION}

The most likely nature of the swelling documented in this study was a granuloma, which was both larger and longer-lasting than has generally been described as a reaction to other implantable tags. This was likely caused by the presence of a broken sub- mounted housing with 2 sub-dermal attachments, one of which broke on impact (see Fig. 2a1,a2). It was again observed with a new calf in the winter of 1996, but no photographs of the left side were taken. A photograph taken off California (CRC ID \#1573) on 20 June 1999 revealed a moderate circular swelling of 30 to $60 \mathrm{~cm}$ in diameter on the whale's left flank where the tag had been attached (Fig. 1a). In winter 2000, the whale was observed without good photographs of the left side. Photographs taken in winter from 2002 to 2005 showed a larger swelling of $>60 \mathrm{~cm}$ in diameter (Fig. 1b,c) and the still implanted sub-dermal attachment visible at its center (Fig. 2b, Table 1). In 2006, a photograph of the whale revealed that the sub-dermal attachment had been expelled, leaving an open wound with blubber tissue apparently visible at the center of the swelling, which appeared to have decreased in size compared to 2004 (Figs. 1d \& 2c). In 2007 the whale was photographed, but only the caudal fin was visible so the site of swelling was not observable

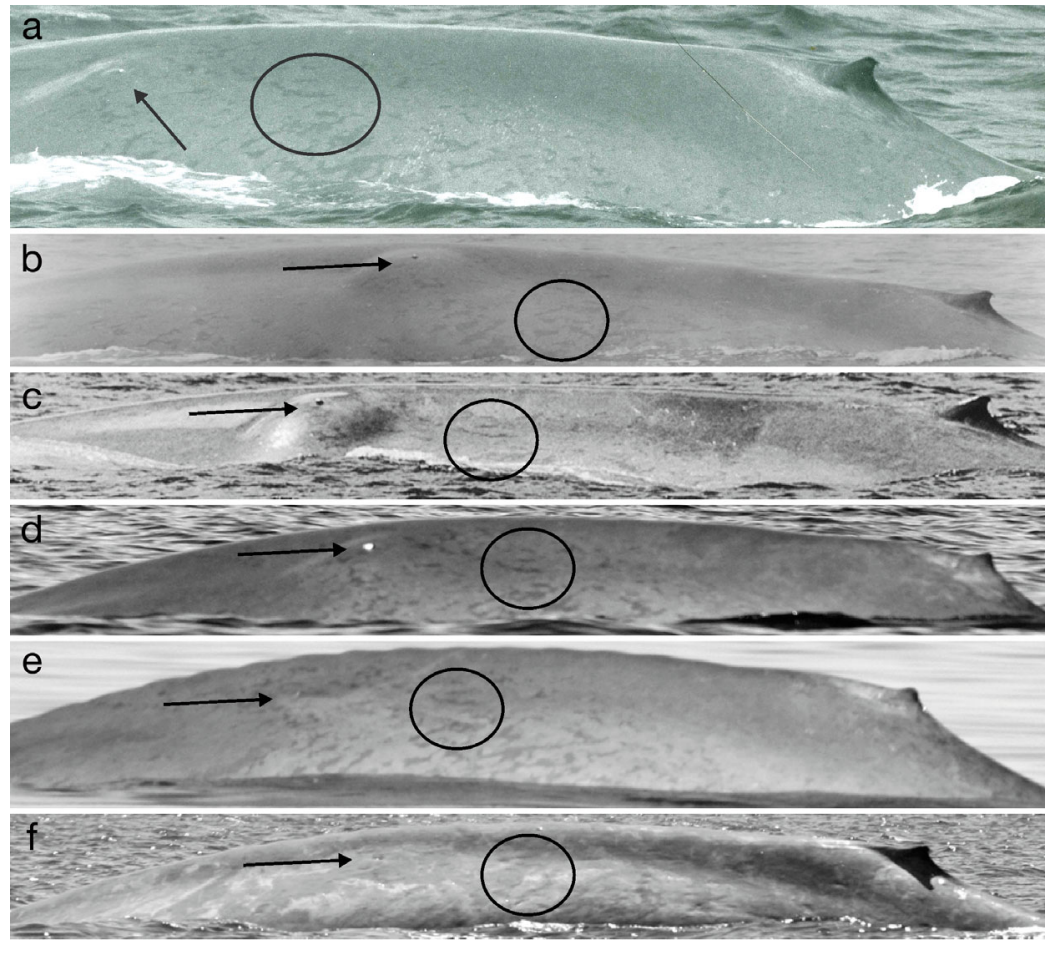

Fig. 1. Photographs of the tagged blue whale taken in (a) 1999, (b) 2002, (c) 2004, (d) 2006, (e) 2009 and (f) 2011 with clear swelling showing on the left flank from (a-c) 1999 to 2004. In (d) 2006 the tag attachment had been expelled, and by (e) 2009 the inflammation had vanished leaving a visible scar in (f) 2011. Arrows show the tagging area and circles indicate the pigmentation pattern used to match the whale's photographs 

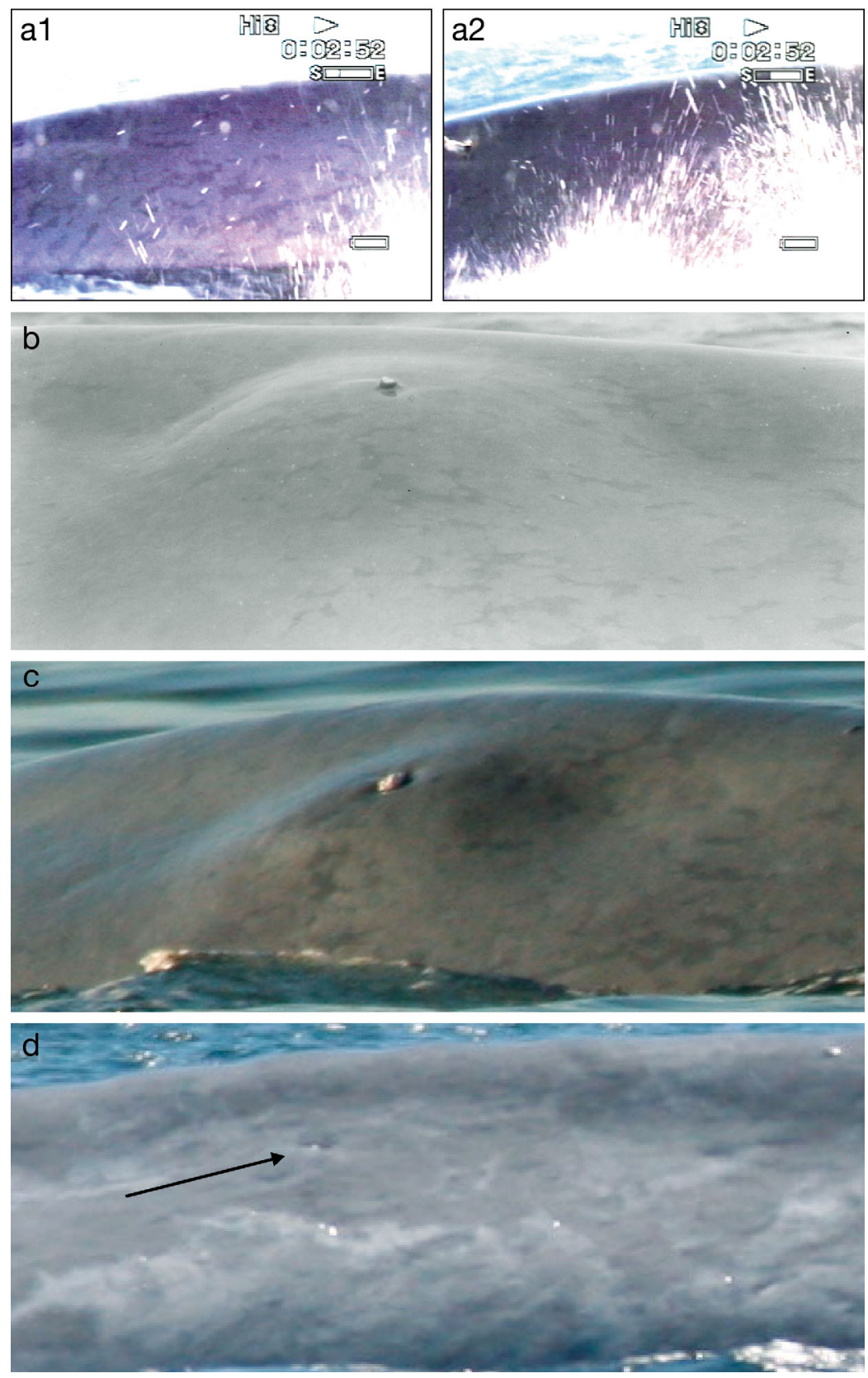

Fig. 2. Enlargement of the blue whale tag area showing (a1) a close up of the whale before implantation and (a2) with the sub-dermal attachment broken in 1995 as shown on the extreme left of the whale image, (b) progression of the inflammation in 2002; (c,d) after expulsion, showing (c) exposed blubber tissue at the center of the granuloma in 2006 and (d) a visible scar in 2011 (arrow)

dermal attachment that remained embedded in the whale for $10 \mathrm{yr}$. Without an external portion of the tag exposed to generate drag, the embedded attachment may have taken much longer than normal to shed, perhaps contributing to both the larger size and duration of the swelling. Another explanation may be a galvanic reaction from the use of dissimilar metals in the attachments (stainless steel shaft and bronze temple toggle) that could have led to irritation while the attachment remained in the whale.

Subsequent veterinary advice (when the electronics packages became small enough) suggested implanting tags into the muscle layer so that attachments could deploy below the tough fascia at the blubber-muscle interface, in order to enhance long-term tag attachment and encourage encapsulation. However, a recent report on metal implant lesions in a North Atlantic right whale confirmed that a foreign object (a pointed needle) implanted through the blubber into the muscle may damage the muscle (because it is fixed in the blubber) while the blubber moves relative to the muscle as the animal swims (Moore et al. 2012). Veterinarians do not agree whether tagrelated swellings are caused by infection or a foreign body response (Mate et al. 2007). In the case reported here, the tag attachment was ultimately expulsed but remained implanted in the whale for a long period (1995 to 2005), a situation that may have resulted in stress to the animal.

For an endangered species such as the blue whale, monitoring and mitigation of all sources of stress should be a management goal. This particular population of blue whales is known to be susceptible to mortality from ship strikes off the coast of California during its seasonal feeding association with the area (Berman-Kowalewski et al. 2010). As both shipping traffic and number of blue whales increase in the area, the potential for future ship strikes will likely continue (BermanKowalewski et al. 2010). Anthropogenic noise may also pose a stress to whales. Melcón et al. (2012) showed blue whales exhibiting an acoustical response to midfrequency active sonar and ship noise in the Southern California Bight, but the implications of such a response are currently unknown. Overall, chronic stress (affecting reproductive hormones) may lead to lower reproductive success in terrestrial mammals (Nelson 2011), and similar effects are likely in marine mammals (St. Aubin 2001). 
In 2009, 3 yr after the last observed swelling, the female blue whale was observed without a calf, but was emaciated (Fig. 1e), which is a characteristic of lactating females (Gendron 2002). Thus, it is possible that the female had a calf in 2009 that we did not observe, or that emaciation was associated with nutritionallystressed conditions because of poor food supply. According to the Multivariate ENSO Index (MEI; Wolter \& Timlin 1993, 1998), El Niño-like anomalies (which could have led to poor conditions for calving) were predominant during 2002 to 2006 and 2009 (www. esrl.noaa.gov/psd/enso/mei/). With a mean calving interval of $2.57 \mathrm{yr}$, and a range of 2 to $4 \mathrm{yr}$ for adult females in this population (Sears et al. 2013), the absence of a calf during the swelling period may seem unusual and suggest an apparent decline in this female's reproductive success. Monitoring post-tagging reproductive success in 7 southern right whales, Best \& Mate (2007) reported an average calving interval of $3.2 \mathrm{yr}$ (the same as the pre-tagging interval), although all tags were shed in less than 3 yr.

Walker et al. (2011) recommended weighing possible long-term consequences of tagging against tagging program goals, especially for endangered species. The persistent period of swelling seen on whale ID \#75 occurred for a tag design from 1995. Continued evolution in tag technology has led to smaller tag designs that could be almost fully implanted into a whale's back with only an antenna end cap exposed, thus decreasing hydrodynamic drag and eliminating most attachment breakage. Despite the concerns we have about the calving interval of this particular whale, we believe that the results from tagging have enabled a better understanding of habitat use, including female seasonal residencies, which can help to promote better conservation and management strategies. However, such studies should, where feasible, include post-attachment monitoring to assess the consequences of tagging. Several workshops on large whale tagging have indeed recommended monitoring tagged whales to study potential tagging effects. While such studies may be difficult to carry out on populations that dwell far from shore, some retrospective examinations and new tagging studies involving long-term follow-up are underway. It would be advantageous to tag whales with a sighting history, if possible, to ensure high individual re-sighting probability, better monitor the long-term effect of tags, and enhance the scope of the research through more detailed information of movement by sex or age class. When long-term data are not available, a monitoring program using the location data from the tagged whales would be desirable when feasible.
The link between certain blue whales feeding off California in summer and wintering in the Gulf of California was revealed long ago through the use of photo-identification (Calambokidis et al. 1990), and this documented whale is another example of such movement which has been well-illustrated using satellite tag technology (Bailey et al. 2009). The results presented in this paper highlight the importance of collaboration in such efforts, involving the contributions of 3 different organizations and providing follow-up information on a tagged animal over a 16 yr period. These results also highlight the value of long-term monitoring programs for evaluating the impacts of technology on endangered species.

Acknowledgements. The annual fieldwork was funded by the Instituto Politécnico Nacional and research was done under our annual research permits (1994 to 2000) issued by Secretaria de Medio Ambiente y Pesca and (2001 to 2011) by the Dirección General de Vida Silvestre, Secretaria de Medio Ambiente y Recursos Naturales. We are grateful to all the students, volunteers and technicians from the Laboratorio de Ecología de Cetáceos y Quelonios at CICIMAR-IPN who collaborated during the fieldwork, and Armando Hernandez Lopez for editing the figures. We thank all Mingan Islands Cetacean Research (MICS) personnel who took part in many years of fieldwork in the Loreto region. We thank Kiirsten Flynn, who was able to photographically match this whale to the video images taken during tag deployment. Her participation and that of J.C. was conducted with the support of the Office of Naval Research under grant N00014-10-1-0902. Todd Chandler and others at Cascadia Research obtained some of the photographs off California used in this study. The tagging of this whale was carried out under NOAA MMPA/ESA permit \#841 and was funded by an ONR grant to Oregon State University and supplemented by donor gifts to the Oregon State University Foundation for the OSU Marine Mammal Program. Comments on the draft manuscript by Barbara Lagerquist were helpful preparing the final form of the paper.

\section{LITERATURE CITED}

Acevedo-Whitehouse K, Rocha-Gosselin A, Gendron D (2010) A novel noninvasive tool for disease surveillance of large free-ranging whales and its relevance to conservation programs. Anim Conserv 13:217-225

Andrews RS, Pitman RL, Ballance LT (2008) Satellite tracking reveals distinct movement patterns for Type $\mathrm{B}$ and Type C killer whales in the southern Ross Sea, Antarctica. Polar Biol 31:1461-1468

Bailey H, Mate BR, Palacios DM, Irvine L, Bograd SJ, Costa DP (2009) Behavioural estimation of blue whale movements in the Northeast Pacific from state-space model analysis of satellite tracks. Endang Species Res 10: 93-106

Baird RW, Hanson MB, Schorr GS, Webster DL and others (2012) Range and primary habitats of Hawaiian insular false killer whales: informing determination of critical habitat. Endang Species Res 18:47-61 
Berman-Kowalewski M, Gulland FMD, Wilkin S, Calambokidis J and others (2010) Association between blue whale (Balaenoptera musculus) mortality and ship strikes along the California coast. Aquat Mamm 36: 59-66

Best PB, Mate B (2007) Sighting history and observations of southern right whales following satellite tagging off South Africa. J Cetacean Res Manag 9:111-114

Block BA, Jonsen ID, Jorgensen SJ, Winship AJ and others (2011) Tracking apex marine predator movements in a dynamic ocean. Nature 475:86-90

Calambokidis J, Barlow J (2004) Abundance of blue and humpback whales in the eastern North Pacific estimated by capture-recapture and line-transect methods. Mar Mamm Sci 20:63-85

Calambokidis J, Steiger GH, Cubbage JC, Balcomb KC and others (1990) Sightings and movements of blue whales off Central California 1986-1988 from photo-identification of individuals. Rep Int Whal Comm (Spec Issue) 12: 343-348

Calambokidis J, Barlow J, Ford JKB, Chandler TO, Douglas AB (2009) Insights into the population structure of blue whales in the eastern North Pacific from recent sightings and photographic identification. Mar Mamm Sci 25: 816-832

> Costa-Urrutia P, Sanvito S, Victoria-Cota N, Enriquez-Paredes L, Gendron D (2013) Fine-scale population structure of blue whale wintering aggregation in the Gulf of California. PLoS ONE 8:e58315

Croll DA, Tershy BR, Hewitt RP, Demer DA and others (1998) An integrated approach to the foraging ecology of marine birds and mammals. Deep-Sea Res II 45:1353-1371

> Davis RW, Jaquet N, Gendron D, Bazzino G, Markaida U, Gilly W (2007) Diving behavior of sperm whales in relation to behavior of a major prey species, the jumbo squid, in the Gulf of California, Mexico. Mar Ecol Prog Ser 333: 291-302

> Durban JW, Pitman RL (2012) Antarctic killer whales make rapid, round-trip movements to subtropical waters: Evidence for physiological maintenance migrations? Biol Lett 8:274-277

Etnoyer P, Canny D, Mate B, Morgan L (2004) Persistent pelagic habitats in the Baja California to Bering Sea (B2B) Ecoregion. Oceanography 17:90-101

Flores-Cascante L, Gendron D (2012) Application of McMaster's technique in live blue whales. Vet Rec 171: 220

> Garrigue C, Zerbini AN, Geyer Y, Heide-Jørgensen MP, Hanaoka W, Clapham P (2010) Movements of satellitemonitored humpback whales from New Caledonia. J Mammal 91:109-115

Gendron D (2002) Ecologia poblacional de la ballena azul, Balaenoptera musculus, de la Peninsula de Baja California. Doctoral thesis, Centro de Investigacion Cientifica y de Educacion Superior de Ensenada (in Spanish)

Gendron D, Ugalde de la Cruz A (2012) A new classification method to simplify blue whale photo-identification technique. J Cetacean Res Manag 12:79-84

Goodyear JD (1993) A sonic/radio tag for monitoring dive depths and underwater movements of whales. J Wildl Manag 57:503-513

Hazen EL, Maxwell SM, Bailey H, Bograd SJ and others (2012) Ontogeny in marine tagging and tracking science: technologies and data gaps. Mar Ecol Prog Ser 457: 221-240
Heide-Jørgensen MP, Laidre KL, Jensen MV, Dueck L, Postma LD (2006) Dissolving stock discreteness with satellite tracking: bowhead whales in Baffin Bay. Mar Mamm Sci 22:34-45

Kennedy AS, Zerbini AN, Vázquez OV, Gandilhon N, Clapham PJ, Adam O (2013) Local and migratory movements of humpback whales (Megaptera novaeangliae) satellite-tracked in the North Atlantic Ocean. Can J Zool 92:8-17

> Martinez-Levasseur LM, Gendron D, Knell RJ, O'Toole EA, Singh M, Acevedo-Whitehouse K (2011) Acute sun damage and photoprotective responses in whales. Proc R Soc Lond B Biol Sci 278:1581-1586

Martinez-Levasseur LM, Birch-Machin MA, Bowman A, Gendron D, Weatherhead E, Knell RJ, Acevedo-Whitehouse K (2013) Whales use distinct strategies to counteract solar ultraviolet radiation. Sci Rep 3:2386

> Mate BR, Harvey JT (1983) A new attachment device for radio-tagging large whales. J Wildl Manag 47:868-872

> Mate BR, Lagerquist BA, Calambokidis J (1999) Movements of North Pacific blue whales during the feeding season off southern California and their southern fall migration. Mar Mamm Sci 15:1246-1257

> Mate BR, Mesecar R, Lagerquist B (2007) The evolution of satellite-monitored radio tags from large whales: one laboratory's experience. Deep-Sea Res II 54:224-247

Melcón ML, Cummins AJ, Kerosky SM, Roche LK, Wiggins SM, Hildebrand JA (2012) Blue whales respond to anthropogenic noise. PLoS ONE 7:e32681

Mizroch SA, Tillman MF, Jurasz S, Straley JM and others (2011) Long-term survival of humpback whales radiotagged in Alaska from 1976 through 1978. Mar Mamm Sci 27:217-229

Moore M, Andrews R, Austin T, Bailey J and others (2012) Rope trauma, sedation, disentanglement, and monitoring-tag associated lesions in a terminally entangled North Atlantic right whale (Eubalaena glacialis). Mar Mamm Sci 29:E98-E113

Nelson RJ (2011) An introduction to behavioral endocrinology, $4^{\text {th }}$ edn. Sinauer Associates, Sunderland, MA,

> Pike DG, Víkingsson GA, Gunnlaugsson Th, Øien N (2009) A note on the distribution and abundance of blue whales (Balaenoptera musculus) in the central and northeast North Atlantic. NAMMCO Sci Publ 7:19-29

> Ramp C, Bérubé M, Hagen W, Sears R (2006) Survival of adult blue whales Balaenoptera musculus in the Gulf of St. Lawrence, Canada. Mar Ecol Prog Ser 319:287-295

Robbins J, Zerbini AN, Gales N, Gulland FMD and others (2013) Satellite tag effectiveness and impacts on large whales: preliminary results of a case study with Gulf of Maine humpback whales. Paper No. SC/65a/SH05. Proc 65th Scientific Committee of the International Whaling Commission, Jeju, South Korea, June 2013

Schorr GS, Baird RW, Hanson MB, Webster DL, McSweeney DJ, Andrews RD (2009) Movements of satellite-tagged Blainville's beaked whales is off the island of Hawaii. Endang Species Res 10:203-213

Sears R, Williamson JM, Wenzel FW, Bérubé M, Gendron D, Jones PW (1990) Photographic identification of the blue whale (Balaenoptera musculus) in the Gulf of St. Lawrence, Canada. Rep Int Whal Comm (Spec Issue) 12:335-342

Sears R, Ramp C, Douglas AB, Calambokidis J (2013) Reproductive parameters of eastern North Pacific blue whales Balaenoptera musculus. Endang Species Res 22: $23-31$ 
St. Aubin D (2001) Chapter 10: endocrinology. In: Dierauf LA, Gulland FMD (eds) CRC handbook of marine mammal medicine. CRC Press, Boca Raton, FL, p 165-192

Ugalde de la Cruz A (2008) Abundancia y tasa de supervivencia de la ballena azul del Golfo de California. MSc thesis, Centro Interdisciplinario de Ciencias Marinas, Instituto Politecnico Nacional, La Paz (in Spanish)

Walker KA, Trites AW, Haulena M, Weary DM (2011) A review of the effects of different marking and tagging techniques on marine mammals. Wildl Res 39:15-30

Wall D, O'Kelly I, Whooley P, Tyndall P (2009) New records of blue whales (Balaenoptera musculus) with evidence of possible feeding behaviour from the continental shelf slopes to the west of Ireland. Mar Biodivers Rec 2:1-4

Watkins WA, Tyack PL (1991) Response of sperm whales

Editorial responsibility: Karina Acevedo-Whitehouse, Queretaro, Mexico
(Physeter catodon) to tagging with implanted sonar transponder and radio tags. Mar Mamm Sci 7:409-413

Wolter K, Timlin MS (1993) Monitoring ENSO in COADS with a seasonally adjusted principal component index. In: Proceedings of the $17^{\text {th }}$ climate diagnostics workshop. NOAA/NMC/CAC, NSSL, Oklahoma Climate Survey, CIMMS and the School of Meteorology, University of Oklahoma, Norman, OK, p 52-57

Wolter K, Timlin MS (1998) Measuring the strength of ENSO events: How does 1997/98 rank? Weather 53:315-324

Zerbini AN, Andriolo A, Heide-Jørgensen MP, Pizzorno JL and others (2006) Satellite-monitored movements of humpback whales Megaptera novaeangliae in the Southwest Atlantic Ocean. Mar Ecol Prog Ser 313: 295-304

Submitted: August 5, 2013; Accepted: August 22, 2014 Proofs received from author(s): November 14, 2014 